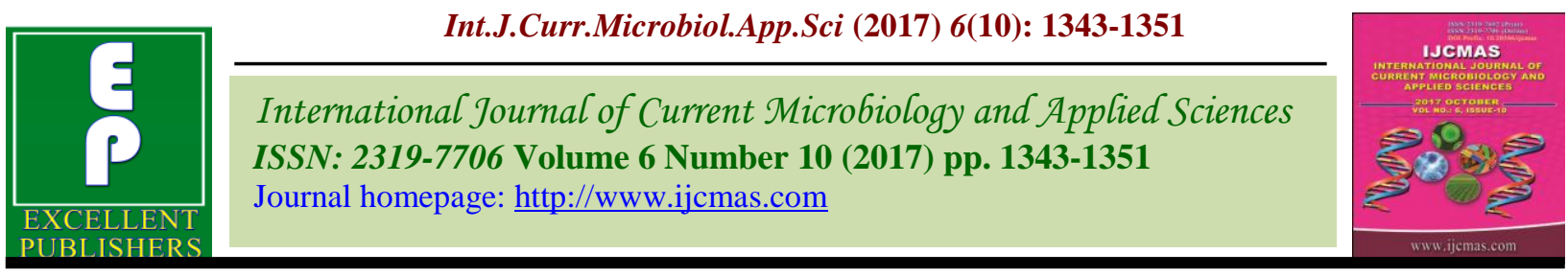

Original Research Article

https://doi.org/10.20546/ijcmas.2017.610.158

\title{
Native Trichoderma spp for the Management of Stem Rot of Groundnut Caused by Sclerotium rolfsii Sacc in Manipur, India
}

\author{
Kh. Rashmi ${ }^{1}$, Bireswar Sinha ${ }^{1}$, Kh. Pramesh ${ }^{2}$ and Ph. Sobita Devi ${ }^{1}$ \\ ${ }^{1}$ Department of Plant Pathology, College of Agriculture, \\ ${ }^{2}$ AICRP (Groundnut), Directorate of Research, Central Agricultural University, \\ Imphal-795004, Manipur, India \\ *Corresponding author
}

\begin{tabular}{|c|c|}
\hline & A B S T R A C T \\
\hline & \multirow{6}{*}{$\begin{array}{l}\text { A total of seven isolates of two different Trichoderma spp. were isolated from the } \\
\text { rhizosphere of groundnut from different locations of Manipur. In vitro study on the effect } \\
\text { of Trichoderma isolates on the growth of Sclerotium rolfsii ranges from } 71.85-61.11 \text { per } \\
\text { cent. Effect of volatile compound produced by Trichoderma spp. against } S \text {. rolfsii showed } \\
\text { inhibition ranged from } 20.00 \text { - } 30.00 \text { per cent and for non-volatile compound } 11.47-30.7 \\
\text { per cent at } 7.5 \% \text { v/v concentrations and } 20.77-47.78 \text { per cent at } 15 \% \text { v/v. Experiment on } \\
\text { ecological adaptability of two potent } T \text {. viride showed variation in the colonization of } \\
\text { sclerotia under three different soil conditions. The rhizosphere competence of two potent } \\
\text { isolates of } T \text {. viride viz., TvG1 andTvG } 2 \text { at different days after sowing showed variation in } \\
\text { the levels of colonization under three different soil conditions. In vivo study on efficacy of } \\
\text { two potent isolates showed reduction in stem rot of groundnut among the different } \\
\text { treatments (seed, soil and seed plus soil). The treatment with seed + soil of Trichoderma } \\
\text { isolates TvG1 and TvG } 2 \text { recorded the highest plant height, plant canopy, fresh weight, dry } \\
\text { weight and yield, but no significant difference in chlorophyll content among treatments. }\end{array}$} \\
\hline Keywords & \\
\hline $\begin{array}{l}\text { Native, Volatile, } \\
\text { Non-volatile, } \\
\text { Sclerotia, Ecology. }\end{array}$ & \\
\hline Article Info & \\
\hline $\begin{array}{l}\text { Accepted: } \\
\text { 14 September } 2017 \\
\text { Available Online: } \\
10 \text { October } 2017\end{array}$ & \\
\hline & \\
\hline
\end{tabular}

\section{Introduction}

Groundnut (Arachis hypogeae L.) is an important oilseed crop of tropical and subtropical region of the world. It is native of South America and belongs to annual legume group. Groundnut kernel is rich source of energy because of its oil (44-48\%) and protein content (25-36\%) than meat, about two and a half times than in eggs, and far more than any other vegetable food except soybean and yeast. In India it is grown mainly in Gujarat, Maharashtra, Andhra Pradesh, Uttar Pradesh, Tamil Nadu, Rajasthan, Karnataka and Madhya Pradesh. The crop is known to be attacked by number of fungal, bacterial and viral diseases.
The literature reveals that the yield losses caused by major fungal disease like leaf spot, rust and soil borne diseases like stem rot, root rot, collar rot and pod rot singly or in combination as high as $15-70 \%$ during both kharif and rabi-summer season (Subramanyam et al., 1984). The stem rot of groundnut is caused by pathogen (Sclerotium rolfsii Sacc.) is a soil inhibitant, polyphagous, facultative fungal parasite. It is documented that the fungal has host range of 500 plant species including several cultivated field and vegetables crops and many others (Aycock 1966).The fungus survived in the soil for many years by producing sclerotial bodies 
and causing the disease either in the form of stem rot or root rot in addition to blight on several of its host (Garret, 1956).

Trichoderma, a saprophytic fungus is known to be one of the best candidates of biocontrol agents for the management of soil borne plant pathogens. The antagonistic action of Trichoderma species against phytopathogenic fungi might be due to either by secretion of extra cellular hydrolytic enzyme (Di Pietro et al., 1993; Schirmbock et al., 1994) or by the production of antibiotics (Dennis and Webster, 1971a, b).

Manipur is likely to harbour useful Trichoderma isolates. So far not much previous research has been done on the use of native microbial agents for the management of stem rot disease of groundnut in this region.

Therefore, the present study was conducted to understand on the occurrence of stem rot of groundnut caused by Sclerotium rolfsii Sacc. and its management by native Trichoderma spp in Manipur.

\section{Materials and Methods}

\section{Fungal identification and pathogenicity test}

Collection of the disease samples and isolation of causal pathogen involved

Diseased plants were collected from the field and the samples were cut into small pieces of $1 \mathrm{~mm}$ size, then surface sterilized with $0.1 \%$ sodium hypochlorite solution for 1 minute and rinsed with distilled water. The sterilized pieces were then inoculated on PDA slants. The inoculated slants were incubated at $28 \pm$ $1^{0} \mathrm{C}$ and fungal growth appearing on the sample was identified in the laboratory and culture was maintained on PDA slants for further use.

\section{Pathogenicity test}

Pathogenicity test of the isolated fungus was conducted. Soil inoculation with pathogen was done by means of rice seed inoculums technique of Weideman and Wehner (1993).

Biocontrol of Sclerotium rolfsii Sacc. by native Trichoderma spp.

\section{Collection of soil sample from rhizosphere of groundnut}

The soil samples were collected from the rhizosphere of groundnut plant of Manipur at a depth ranged in 5-6 cm by removing $2 \mathrm{~cm}$ surface soil.

The soil was air dried under shade and kept sealed in cloth bag inside refrigerator at $4^{\circ} \mathrm{C}$ for subsequent use whenever required.

\section{Isolation of the antagonists}

Different Trichoderma spp. were isolated from different areas by soil dilution plate technique (Dhingra and Sinclair, 1995) using Trichoderma specific medium (TSM) (Elad and Chet, 1983) modified by Saha and Pan (1997).

All the identified species of Trichoderma were maintained in potato dextrose agar (PDA) slants and preserved inside the refrigerator at $4^{\circ} \mathrm{C}$ for subsequent use.

\section{In vitro antagonistic potential of some isolates of Trichoderma}

In vitro antagonistic potential of isolates of Trichoderma spp. were evaluated against Sclerotium rolfsii Sacc. Through dual culture technique (Morton and Stroube, 1955), production of volatile (Dennis and Webster, 1971b) and non-volatile antibiotics (Dennis and Webster, 1971a). 


\section{Ecological fitness of Trichoderma isolates}

Ecological fitness of Trichoderma spp. was carried out in laboratory and pot experiment using the soil of Manipur. The ecological studies included the competitive parasitic ability and rhizosphere colonization by isolates of Trichoderma. Three soil types, viz., unsterilized, sun dried and sterilized soil were used by following the methods of Papavizas (1982).

\section{In vivo Efficacy of Trichoderma isolates}

Field experiment on efficacy of Trichoderma isolates against stem rot of groundnut was conducted at Sangaiprou Maning Leikai, Imphal. Field trails were taken up in randomized block design (RBD) with three replications with plot sizes of $1.5 \mathrm{~m} \times 3 \mathrm{~m}$.

Each plot was treated with $200 \mathrm{gm}$ of pathogen mixture before planting of groundnut variety ICGS- 76 and untreated plots were served as control. The two potent isolates viz., TvG1 and TvG2 were used with different treatment combination as seed, soil treatment and combination of two (seed and soil) and observation on yield parameters including chlorophyll contents (by SPAD meter at 30,60 and 90 DAP) were recorded both pot and field experiments.

\section{Results and Discussion}

\section{Fungal identification and pathogenicity test}

Diseased samples collected from farmer's field during the survey were brought to laboratory and isolation was done and with repeated isolations, Sclerotium rolfsii was consistently found with the infected plant of groundnut. S. rolfsii cultures isolated from the infected groundnut were identified based on the types of fungal mycelium and mustard shaped of sclerotia as compared with the old cultures available in the laboratory,
Department of Plant Pathology, COA, CAU, Imphal. Pathogenicity test of $S$. rolfsii was carried out as described in materials and methods.

\section{Biocontrol of Sclerotium rolfsii Sacc.by native Trichoderma spp.}

\section{Isolation and identification of Trichoderma} spp.

Soils collected from rhizosphere of different groundnut growing areas of Manipur were tested and Trichoderma isolates were identified based on morphology and taxonomic keys mentioned by Rifia (1969) and altogether seven Trichoderma isolates were isolated from different groundnut growing areas and among these, two were Trichoderma viride and five were Trichoderma harzianum and was reconfirmed from National Centre for Integrated Pest Management, New Delhi.

In vitro antagonistic potential of some isolates of Trichoderma

\section{Mycelial growth inhibition}

Mycelial growth inhibition of Trichoderma spp. against $S$. rolfsii Sacc. is presented in table 1. Among the isolates of Trichoderma spp. tested, maximum percentage inhibition was recorded with isolate TvG1 (71.85 per cent) and minimum was observed with the isolate ThrG4 (61.11 per cent).

\section{Effect of volatile antibiotics}

Effect of volatile compounds produced by Trichoderma spp. against S.rolfsiiSacc.is presented in table 1. Among the seven isolates of Trichoderma spp. tested, maximum percentage inhibition was recorded with isolate ThrG1 (30.00 per cent) and minimum was recorded with isolate ThrG7 (20.00 per cent). 


\section{Effect of non-volatile antibiotics}

Effect of non-volatile compounds produced by Trichoderma spp. at two different concentrations viz., $7.5 \%(\mathrm{v} / \mathrm{v})$ and $15 \%(\mathrm{v} / \mathrm{v})$ are presented in table 1 . Results showed that per cent inhibition of radial growth of $S$. rolfsii Sacc. by seven isolates of Trichoderma spp. ranged from 11.47 - 30.37 percent at $7.5 \% \mathrm{v} / \mathrm{v}$ concentration and from $20.77-47.78$ percent at $15 \% \mathrm{v} / \mathrm{v}$.

Competitive parasitic ability of potent Trichoderma spp. against $S$. rolfsii

Competitive parasitic ability of the two potential isolates of Trichoderma against $S$. rolfsii is presented in table 2 . It is revealed from table that the colonization percentage of sclerotia of $S$. rolfsii by TvG1 and TvG2 in unsterilized soil was 86.67 percent and 73.33 percent, while in sundried soil colonization percentage were 73.33 percent and 66.67 percent.

The degrees of colonization in sterilized soil were 100 percent by the isolates.

\section{In vivo efficacy of Trichoderma isolates}

In vivo efficacy of two potent isolates viz., TvG1 and TvG2 of Trichoderma were evaluated against $S$. rolfsii under field and pot conditions with different treatments viz., seed treatment, soil treatment and combination of seed and soil.

Table.1 Effect of different Trichoderma isolates on growth of S. rolfsii

\begin{tabular}{|c|c|c|c|c|c|}
\hline \multirow{3}{*}{$\begin{array}{l}\text { Sl } \\
\text { No }\end{array}$} & \multirow{3}{*}{$\begin{array}{l}\text { Trichoderma } \\
\text { spp. }\end{array}$} & \multirow{3}{*}{$\begin{array}{c}\text { Inhibition } \\
(\%)\end{array}$} & \multicolumn{3}{|c|}{$\begin{array}{l}\text { Percent inhibition over control } \\
\end{array}$} \\
\hline & & & \multirow{2}{*}{$\begin{array}{c}\text { Volatile } \\
\text { compounds }\end{array}$} & \multicolumn{2}{|c|}{ Nonvolatile compounds } \\
\hline & & & & $(7.5 \%)$ & $(15 \%)$ \\
\hline 1 & TvG1 & 71.85 & $30.00(5.57) *$ & $30.37(33.43)^{*}$ & 47.78(43.74) \\
\hline 2 & TvG2 & 71.11 & $27.78(5.27)$ & $20.47(26.90)$ & 27.41(31.58) \\
\hline 3 & ThrG3 & 64.07 & $23.33(4.82)$ & $12.96(20.75)$ & $20.97(27.25)$ \\
\hline 4 & ThrG4 & 61.11 & $22.22(4.71)$ & $13.33(21.38)$ & $22.22(28.11)$ \\
\hline 5 & ThrG5 & 97.78 & $27.04(5.20)$ & $18.17(25.23)$ & 27.04(31.35) \\
\hline 6 & ThrG6 & 61.85 & $29.70(5.45)$ & $11.47(19.79)$ & $20.77(27.11)$ \\
\hline 7 & ThrG7 & 61.48 & $20.00(4.47)$ & $15.93(23.50)$ & 20.93(27.22) \\
\hline \multicolumn{2}{|c|}{ S.E(d) \pm} & 1.38 & 1.52 & 1.64 & 0.69 \\
\hline \multicolumn{2}{|c|}{ C.D. $(5 \%)$} & 3.01 & 3.30 & 3.58 & 1.50 \\
\hline
\end{tabular}

*Mean of three replication

Values in parentheses are transformed values

Table.2 Competitive parasitic ability of Trichoderma spp. against sclerotia of S. rolfsii

\begin{tabular}{|l|l|l|}
\hline Sl.No. & Trichoderma spp. & Colonisation (\%) \\
\hline 1. & TvG1(UN) & $86.67(9.32)$ \\
\hline 2. & TvG2(UN) & $73.33(8.57)$ \\
\hline 3. & TvG1(SD) & $73.33(8.57)$ \\
\hline 4. & TvG2(SD) & $66.67(8.18)$ \\
\hline 5 & TvG1(S) & $100.00(10.02)$ \\
\hline 6 & TvG2(S) & $100.00(10.02)$ \\
\hline 7 & Control & $0.00(0.71)$ \\
\hline S.E(d) \pm & 0.45 \\
\hline C.D. (5\%) & 0.97 \\
\hline
\end{tabular}

$*$ Mean of three replications, $\mathrm{UN}=$ Unsterilized soil, $\mathrm{SD}=\mathrm{Sundried}$ soil and $\mathrm{S}=\mathrm{Sterilized} \mathrm{soil}$ Values in parentheses are Square Root Transformed values 
Table.3 Effect of Trichoderma isolates on yield and yield attributing characters under field condition

\begin{tabular}{|c|c|c|c|c|c|c|c|c|c|c|c|c|c|}
\hline \multirow{2}{*}{$\frac{\dot{g}}{\sigma}$} & \multirow{2}{*}{ 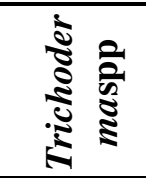 } & \multirow{2}{*}{ 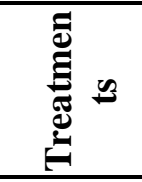 } & \multirow{2}{*}{ 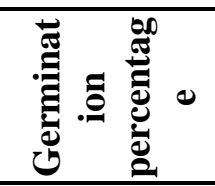 } & \multirow{2}{*}{ 兽 } & \multicolumn{3}{|c|}{$\begin{array}{c}\text { Plant height(cm) } \\
\text { (DAS) }\end{array}$} & \multicolumn{3}{|c|}{$\begin{array}{l}\text { Plant canopy }\left(\mathrm{cm}^{2}\right) \\
\text { (DAS) }\end{array}$} & \multirow{2}{*}{ 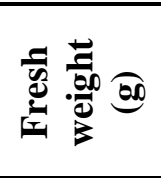 } & \multirow{2}{*}{ 总著 } & \multirow{2}{*}{ 흘 } \\
\hline & & & & & 30 & 60 & 90 & 30 & 60 & 90 & & & \\
\hline \multirow{3}{*}{1} & \multirow{3}{*}{ TvG1 } & Seed & $73.89(8.60)$ & $5.55(2.43)$ & 23.13 & 35.43 & 41.43 & 586.00 & 1883.37 & 2997.53 & 253.33 & 50.67 & 1333.33 \\
\hline & & Soil & $84.44(9.18)$ & $3.33(1.93)$ & 26.73 & 38.03 & 42.03 & 716.40 & 1979.13 & 3724.60 & 271.67 & 54.33 & 1416.67 \\
\hline & & $\mathrm{S}+\mathrm{S}$ & $82.78(9.10)$ & $1.11(1.13)$ & 29.07 & 40.80 & 46.80 & 759.07 & 2113.13 & 3754.40 & 313.33 & 62.67 & 1633.33 \\
\hline \multirow{3}{*}{2} & \multirow{3}{*}{ TvG2 } & Seed & $80.00(8.94)$ & $7.78(2.81)$ & 23.87 & 38.60 & 45.33 & 608.93 & 2061.63 & 2796.73 & 196.67 & 39.33 & 1233.33 \\
\hline & & Soil & $73.89(8.60)$ & $5.55(2.43)$ & 27.00 & 40.33 & 48.60 & 620.93 & 2134.21 & 2997.53 & 216.67 & 43.33 & 1300.00 \\
\hline & & $S+S$ & $80.00(8.95)$ & $0.56(0.96)$ & 27.00 & 43.13 & 50.13 & 640.33 & 2304.98 & 3671.20 & 220.00 & 44.00 & 1433.33 \\
\hline 3 & \multicolumn{2}{|l|}{ Control } & $72.78(8.53)$ & $9.44(3.10)$ & 26.00 & 45.33 & 49.45 & 504.67 & 1631.53 & 1967.47 & 126.67 & 25.33 & 770.00 \\
\hline \multicolumn{3}{|c|}{ 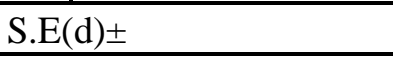 } & 0.19 & 2.07 & \multirow{2}{*}{ NS } & 2.47 & 0.87 & \multirow{2}{*}{ NS } & 43.64 & 70.76 & 12.32 & 2.46 & 158.70 \\
\hline C.D & $(5 \%)$ & & 0.42 & 4.51 & & 5.38 & 1.90 & & 95.08 & 154.18 & 26.85 & 5.37 & 345.80 \\
\hline
\end{tabular}

Values in parentheses are Transformed values, $\mathrm{S}+\mathrm{S}=\mathrm{Seed}+$ Soil

Table.4 Effect of Trichoderma isolates on yield and yield attributing characters under pot trails

\begin{tabular}{|c|c|c|c|c|c|c|c|c|c|c|c|c|c|}
\hline \multirow{2}{*}{$\stackrel{\dot{\Xi}}{\tilde{\sigma}}$} & \multirow{2}{*}{ 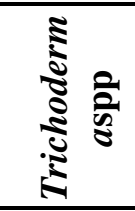 } & \multirow{2}{*}{$\underset{\stackrel{E}{E}}{\stackrel{\vec{E}}{E}}$} & \multirow{2}{*}{ 焉 } & \multirow{2}{*}{ 莺 } & \multicolumn{3}{|c|}{$\begin{array}{c}\text { Plant height }(\mathrm{cm}) \\
(\text { DAS })\end{array}$} & \multicolumn{3}{|c|}{$\begin{array}{c}\text { Plant canopy }\left(\mathrm{cm}^{2}\right) \\
(\text { DAS })\end{array}$} & \multirow{2}{*}{ 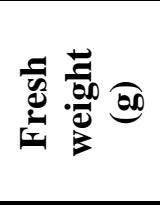 } & \multirow{2}{*}{ 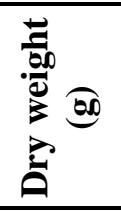 } & \multirow{2}{*}{ 氞 } \\
\hline & & & & & 30 & 60 & 90 & 30 & 60 & 90 & & & \\
\hline \multirow{3}{*}{1} & \multirow{3}{*}{ TvG1 } & Seed & $26.67(30.78)$ & $2.00(1.41)$ & 13.00 & 35.67 & 38.67 & 91.00 & 460.33 & 788.00 & 67.33 & 13.47 & 134.00 \\
\hline & & Soil & $26.67(30.78)$ & $3.67(1.91)$ & 13.00 & 38.99 & 41.33 & 176.33 & 492.33 & 896.67 & 73.33 & 14.80 & 155.00 \\
\hline & & $\mathrm{S}+\mathrm{S}$ & $60.00(50.77)$ & $3.67(1.91)$ & 14.33 & 40.00 & 44.67 & 181.33 & 630.00 & 937.67 & 74.00 & 14.67 & 162.67 \\
\hline \multirow{3}{*}{2} & \multirow{3}{*}{ TvG2 } & Seed & $26.67(30.78)$ & $3.00(1.71)$ & 12.67 & 34.33 & 38.70 & 166.00 & 588.67 & 689.33 & 64.67 & 12.93 & 100.00 \\
\hline & & Soil & $26.67(30.78)$ & $3.67(1.91)$ & 13.33 & 36.67 & 38.82 & 211.33 & 623.33 & 860.67 & 67.00 & 13.40 & 136.00 \\
\hline & & $\mathrm{S}+\mathrm{S}$ & $26.67(30.78)$ & $3.67(1.91)$ & 14.00 & 37.33 & 39.70 & 211.67 & 632.67 & 874.67 & 69.67 & 13.93 & 140.67 \\
\hline 4 & \multicolumn{2}{|l|}{ Control } & $20.00(26.58)$ & $10.00(2.16)$ & 13.00 & 31.33 & 35.37 & 152.67 & 290.33 & 417.00 & 34.00 & 6.80 & 96.67 \\
\hline \multicolumn{3}{|c|}{ S.E (d) \pm} & 5.66 & 0.31 & \multirow{2}{*}{ NS } & 2.56 & 0.98 & \multirow{2}{*}{ NS } & 71.01 & 80.95 & 4.86 & 1.00 & 9.07 \\
\hline C.D & $(5 \%)$ & & 11.89 & 0.66 & & 5.39 & 2.06 & & 149.20 & 170.09 & 10.21 & 2.10 & 19.05 \\
\hline
\end{tabular}

Values in parentheses are Transformed values. S+S= Seed + Soil 
Graph.1 Effect of Trichoderma isolates on chlorophyll content (SPAD UNIT) of groundnut in field trial

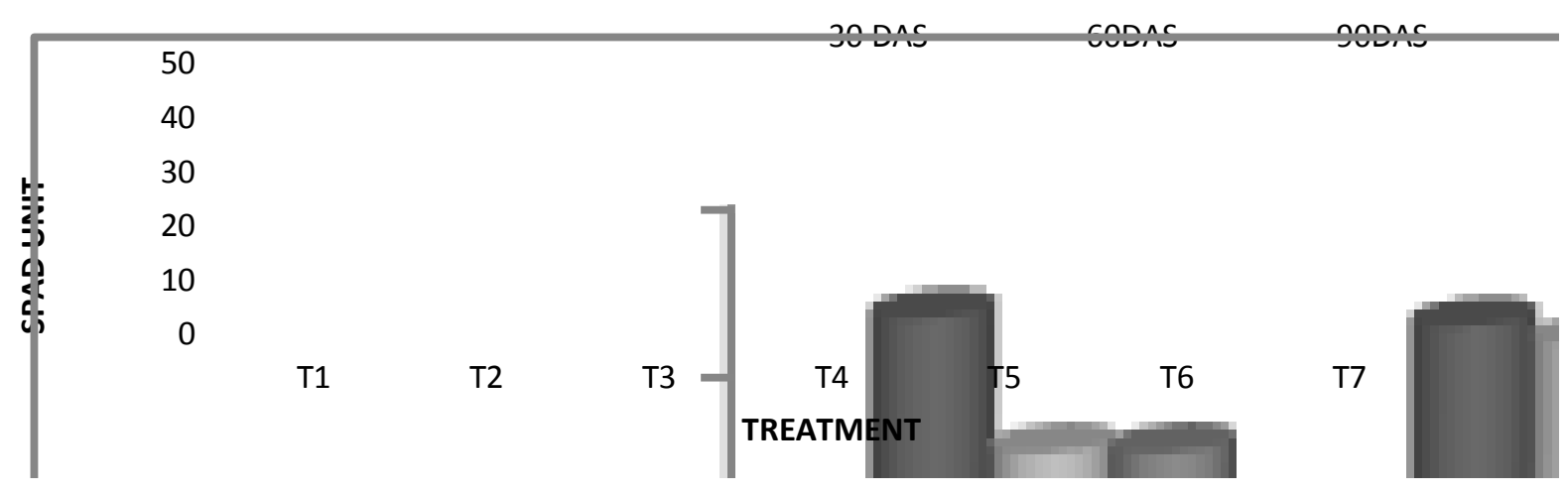

Graph.2 Effect of Trichoderma isolates on chlorophyll content

(SPAD UNIT) of groundnut in pot trial

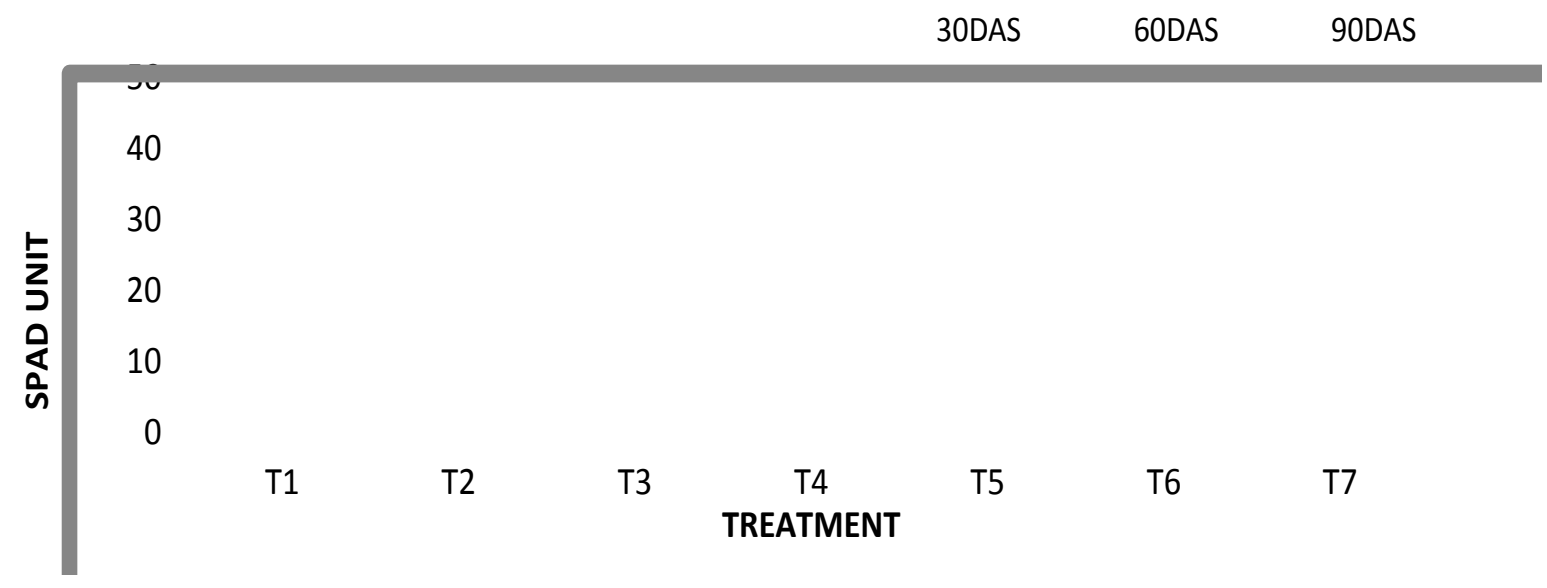

Effect of Trichoderma isolates on the yield and yield attributing characters of groundnut under field conditions

\section{Germination percentage}

The data on germination percentage of groundnut under different treatments of Trichoderma spp are presented in table 3 . The results showed that germination percentage in isolates TvG1 seed treatment, soil treatment and combination of seed and soil treatment were $73.89, \quad 84.44$ and 82.78 percent respectively and in $\mathrm{TvG} 2$, it was $80.00,73.89$ and 80.00 percent respectively.

\section{Disease incidence}

Results on diseases incidence in isolates TvG1 seed, soil and combination of seed and soil treatments were $5.55,3.33$ and 1.11 per cent respectively and in TvG2 7.78, 5.55 and 0.56 per cent respectively (Table 3 ).

\section{Chlorophyll content}

Chlorophyll content of groundnut plants of different treatments are presented in graph 1 and it showed that the chlorophyll content in 30,60 and 90 DAP were 42.07, 41.06 and $34.46,34.14,40.65$ and 39.20 and 34.14 , 40.65 and 39.30 (SPAD unit) in isolates TvG1 
seed, soil and combination of seed and soil treatments respectively and in isolates $\mathrm{TvG} 2$, $40.12,40.35$ and41.37, 37.57, 37.93 and 36.45 and $37.57,39.00$ and 36.45 (SPAD unit) respectively.

\section{Plant height}

Plant height at 30, 60 and 90 DAP showed $23.13-29.07 \mathrm{~cm}, 35.43-40.80 \mathrm{~cm}$ and 41.43 - $46.80 \mathrm{~cm}$ respectively in isolate TvG1 and in TvG2, 23.87 to $27.00 \mathrm{~cm}, 38.60$ to $43.13 \mathrm{~cm}$ and 45.33 to $53.33 \mathrm{~cm}$ respectively in seed, soil and combination of seed and soil treatments, whereas untreated controlled plants height ranged from $26.00-49.45 \mathrm{~cm}$ (Table 3).

\section{Plant canopy}

Plant canopy at 30, 60 and 90DAP showed that in TvG1 seed, soil and seed plus soil treatments ranged from $586.00-759.07 \mathrm{~cm}^{2}$, $1883.37-2113.13 \mathrm{~cm}^{2}$ and $2997.53-3754.40$ $\mathrm{cm}^{2}$ respectively and in isolates TvG2 1 it was 608.93 - $640.33 \mathrm{~cm}^{2}, 2061.63-2304.98 \mathrm{~cm}^{2}$ and $2796.73-3671.20 \mathrm{~cm}^{2}$ respectively (Table 3).

Fresh weight, dry weight and yield of groundnut

The data on fresh weight of groundnut plants in isolate TvG1 treated plot showed highest $313.33 \mathrm{~g}$ (seed + soil treated plot), followed by $271.67 \mathrm{~g}$ (soil) and 253.33g (seed) treated plots. In isolate $\mathrm{TvG} 2$ treated plots, fresh weight showed moderately more or less similar among the treatments. The data on dry weight of groundnut plants in isolate TvG1 treated plot showed highest of $62.67 \mathrm{~g}$ (seed + soil treated plot) followed by $54.33 \mathrm{~g}$ (soil), $50.67 \mathrm{~g}$ (seed) treated plots. Highest yield was obtained of $1630 \mathrm{~g} /$ plot to the TvG1 (seed + soil) treated plot (Table 3 ). The similar trends of the plot experiments were observed as filed experiments (Table 4). It is important to mention that Trichoderma spp. are known to produce a number of antibiotics such as Trichodermin, Trichodermol, Harzianum A, Hrazianolide (Kucuk and Kivanc, 2004) as well as some cell wall degrading enzymes such as chitinases, glucanases that break down polysaccharides, chitins and beta glucanase destroying cell wall (Elad, 2000). Noveriza and Quimio (2004) reported that Trichoderma spp. were able to cause $66.36 \%$ growth inhibition of $P$. capsici through dual culture technique and the pathogens like $R$. solani, Pythium sp., S. rolfsii, Macrophamina phaseolina and Fusarium oxysporum $f$. sp. lycopersici were also significantly inhibited by Trichoderma spp in vitro (Pan and Bhagat, 2008, Rajlakshmi and Bireswar 2014, Sandam et al., 2016). Present investigation also found the different degrees of inhibition on radial growth of Sclerotium rolfsii by different volatile and non-volatile compounds produced by Trichoderma spp. Experiment on ecological adaptability of potent Trichoderma spp. showed variation in the colonization of sclerotia of Sclerotium rolfsii with highest colonization of 100 per cent. These findings are in accordance with Hennis et al., (1983) who have shown that strains of Trichoderma spp. varied in their ability to colonize the sclerotia of Sclerotium rolfsii (Rashmi et al., 2015). Trichoderma treated plants showed greater growth, vigour, chlorophyll content and yield than untreated pathogen inoculated control. Lo et al., (2002) reported that the Trichoderma treated plant promote root growth of bitter gourd, loofah and cucumber. The experiment in greenhouse showed that the plant treated with Trichoderma spp significantly increased seedling height (26 to $61 \%$ ), root exploration (85 to $209 \%$ ) leaf area (27 to $38 \%$ ) and root dry weight (38 to $62 \%$ ) after 15 DAS of bitter gourd. Similarly these Trichoderma strains also increased the seedling growth of loofah and cucumber. Results of chlorophyll content of plants of 
different treatments did not show any significant difference among themselves. However, Satyendra et al., (2012) reported that the concentration of chlorophyll $\left(\mathrm{mg} / \mathrm{cm}^{2}\right.$ of leaves) increased in plant treated with Trichoderma. Moradia et al., (2011) reported that in groundnut, the pod yield was highest i.e. $1427 \mathrm{~kg} / \mathrm{ha}$ in the treatment combination of seed treatment with vitavax + soil application of Trichoderma viride with neem cake where pod yield was increase by 35.1 per cent followed by seed and soil application of Trichoderma viride with neem or castor cake. Our present finding will give idea on the management of stem rot of groundnut by the application of native bio agent (Trichoderma) under filed conditions in Manipur.

\section{References}

Aycock, R. (1966). Stem rot and other diseases caused by Sclerotium rolfsii. North Carolina Agric. Exp. Stn. Tech. Bull., 174-202.

Dennis, C. and Webster, J. (1971a). Antagonists properties of species groups of Trichoderma 1. Production of nonvolatile antibiotics. T. Brit. Mycol. Soc., 57: 25-39.

Dennis, C. and Webster, J. (1971b). Antagonistic properties of species groups of Trichoderma 11.Production of volatile antibiotics. T. Brit. Mycol. Soc., 57: 41-48.

Dhingra, O.P. and Sinclair, J.B. (1995). Basics Plant Pathology methods, $2^{\text {nd }}$ edn.CRC press, Bocca Raton, America.

Di Pietro, A., Lorito, M., Hayes, C.K., Broadway, R.M. and Harman, G.E. (1993). Endochitinase from Gliocladium virens: isolation, characterization and synergistic antifungal activity in combination with gliotoxin. Phytopathol., 83: 308-313

Elad, Y. (2000). Biological control of foliar pathogens by means of Trichoderma harzianum and potential modes of action. Crop Prot., 19: 709-714.

Elad, Y., Chet, I.(1983). Improved selective media for isolation of Trichoderma spp and Fusarium spp., Phytoparasit., 11:55-58.

Garret, S. D. (1956). Towards biological control of plant pathogens. In: Ecology of soil borne plant pathogens, 417(Baker, K.F and Snyder, W. C. Eds.) University of California, Press Berkeley, p: 571.

Kh. Rashmi, B. Sinha and PrameshKh. (2015). Variability of native Trichoderma species isolated from rhizosphere of groundnut (Arachis hypogeael.) In Manipur. The Bioscan, 9(4):1320-1324.

Kucuk, C. and Kivanc, M. (2004).In vitro antifungal activity of strains of Trichoderma harzianum. Turk. J. Biol., 28: 111-115.

Lo, C. T and Lin, C. Y.(2002). Screening strain of Trichoderma spp. for growth enhancement in Taiwan. Plant Pathol. Bull., 11:215-220.

Moradia, A. M. and Khandar, R. R. (2011). Loss of yield of groundnut (Arachis hypogea L.) due to dry root rot (Macrophomina phaseolina) and their management under in vivo condition. Int. J. Agric. Sci., 7(2):282-285.

Morton, D.J. and Stroube, U.H. (1955). Antagonist and stimulatory effect of soil micro-organism upon Sclerotium rolfsii Sacc. Phytopathol., 45: 417-420.

Pan, S. and Bhagat, S. (2008).Characterization of Trichodermaspecies from West Bengal.J. Biol. Control, 22: 43-49

Papavizas, G.C. and Lumsden, R.D. (1982).Improved medium for isolation of Trichoderma spp. from soil. Plant Dis., 66: 1019-1020.

Quimio, T. H. (2001). Workbook on tropical 
fungi. Collection, isolation and identification. The Mycological Society of Philippines, Inc. College, Laguna, Philippines, p: 259.

Rajlakshmi Y., and Bireswar Sinha (2014). In vitro antagonistic potentials of some native Trichoderma spp against stem rot of French bean caused by Sclerotium rolfsii Sacc. in Manipur. Plant Disease Research, 9(1): 41-45.

Saha, D. K. and Pan, S. (1997). Qualitative evaluation of some specific media of Trichoderma and Gliocladium and their possible modifications, J. Mycopathol. Res., 34:7-13.

Satyendra, P.S and Singh, H. B.(2012). Effect of consortium of Trichoderma harzianum on growth attributes and
Sclerotinia sclerotiorum rot of brinjal. Vegetable Sci., 39(2):144-148.

Schirmbock, M., Lorito, M., Wang, Y.L., Hayes, C.K., Arisan-Atlae, I., Scala, F., Harman, G.E. and Kubicek, C.P. (1994).Parallel formation and synergism of hydrolytic enzymes and peptide bond antibiotics, molecular mechanisms involved in the antagonistics action of Trichoderma harzianum against phytopathologenic fungi. Appl. Environ. Microbiol, 7: 4364-4370.

Trina Sandham, PS Devi, Bireswar Sinha. (2016). Native Trichoderma isolates and its impact on growth, fruit yield and disease management of chilli wilt in Manipur. Journal of Mycopathological Research, 54(3): 423-426.

\section{How to cite this article:}

Rashmi, Kh, Bireswar Sinha, Kh. Pramesh and Sobita Devi, Ph. 2017. Native Trichoderma spp for the Management of Stem Rot of Groundnut Caused by Sclerotium rolfsii Sacc in Manipur, India. Int.J.Curr.Microbiol.App.Sci. 6(10): 1343-1351. doi: https://doi.org/10.20546/ijcmas.2017.610.158 